\title{
スパン，層高，鉛直荷重の有無などを変化させた 木質ラーメン架構の実験的研究 \\ EXPERIMENTAL STUDY ON WOODEN SEMI-RIGID PORTAL FRAMES WITH PARAMETERS OF SPAN, HEIGHT AND VERTICAL LOAD
}

山口和弘*, 稲山正弘 ${ }^{* *}$, 志村 智***, 畠山太志***, 河合直 ${ }^{* * * *}$

\section{Kazuhiro YAMAGUCHI, Masahiro INAYAMA, Satoshi SHIMURA, Taishi HATAKEYAMA and Naohito KAWAI}

\begin{abstract}
The purpose of this study is to elucidate the behavior of wooden semi-rigid portal frames with parameters of various design conditions - span, height, vertical load, shear wall on the beam. Under proportion effects of beam depth and length, strength of the frame increases as the span becomes short. Stiffness and strength of the frame decrease as the height becomes high. If the frame have joints with shear-key, stiffness and strength of the frame with vertical load is higher than without vertical load. Yield load of the frame with shear wall on the beam is about the same as without shear wall.
\end{abstract}

Keywords : Wooden semi-rigid frame structure, Moment resisting joints, Portal frame tests, Beam depth, Combined stress, Vertical load 木質ラーメン構造，モーメント抵抗接合部，門型フレーム試験，材せい寸法，複合応力，鉛直荷重

\section{1. はじめに}

「公共建築物における木材の利用の促進に関する法律」が施行さ れ，中・大規模建築物の木造化の流れのなかで，木質ラーメン構造 に注目が集まっている。また，住宅建築においても設計の自由度を 高めるために，木質ラーメンの必要性が高まっている。しかし、現 在は木質ラーメン構造の設計規準が無く, 新しい木質ラーメンのシ ステムを実務の設計において使おうとすると，特定の仕様における 種々の試験を行ったうえで，任意評定などを受ける必要がある。そ のため，一般に木質ラーメン構造の設計をすることが困難である。

木質ラーメン構造のフレームとしての構造性能評価に関する既往 の研究については, 曲げモーメントとせん断力の複合応力に関する 研究 1), 鉛直荷重の影響に関する研究 2), 長期荷重の影響に関する 研究 ${ }^{3)}$, 木質ラーメンフレームと耐力壁の併用に関寸る研究 ${ }^{4)}$, な どがある。しかし、実務上の設計で考えられる様々な設計条件をパ ラメータとして, 同一の接合部により実験を行い, 比較検証を行っ た研究は少ない。

本報では，様々な設計条件をパラメータとする門型フレーム試験 （図 1）を行うことで，スパンをパラメータとした比較，鉛直荷重 の有無による比較, 層高をパラメータとした比較, 梁上耐力壁の有 無による比較などを行う。木質ラーメン構造を用いた構造設計の設 計規準を作成するための基礎資料のひとつとなる。

また合わせて，門型フレーム試験と同仕様の接合部による接合部
試験を行い, 門型フレーム試験の 各接合部のモーメント一回転角関 係（以下， $M-\theta$ 関係）と接合部試験の $M-\theta$ 関係の比較を行い，門型 フレーム試験の各接合部の複合応力の影響の推定を行う。様々な設 計条件をパラメータとする門型フレームの各接合部の応力状態の比 較を行い，木質ラーメン構造の接合部を設計するためのクライテリ アを検討する資料とする。
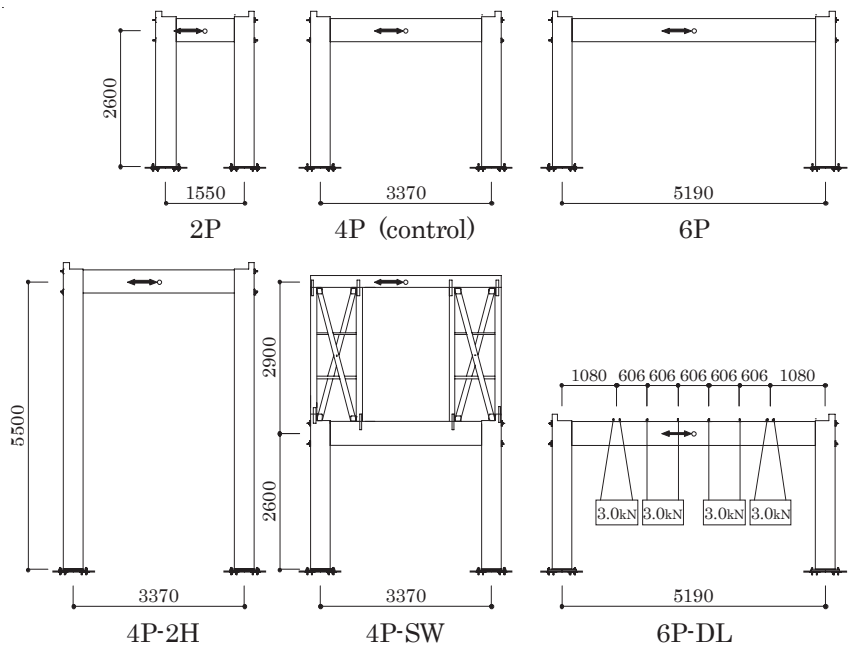

図 1 門型フレーム試験の試験体（6 シリーズ $)$

\footnotetext{
* 東京大学大学院農学生命科学研究科 博士課程 - 農修

** 東京大学大学院農学生命科学研究科 教授. 工博

*** 工学院大学大学院 修士課程
}

**** 工学院大学建築学部 教授.工博
Grad. Student, Grad. School of Agriculture Life Sci., The Univ. of Tokyo, M. Agr. Prof., Grad. School of Agriculture Life Sci., The Univ. of Tokyo, Dr. Eng. Grad. Student, Grad. School of Eng., Kogakuin University Prof., School of Architecture, Kogakuin University, Dr. Eng. 


\section{2. 試験の目的と方法}

\section{1 門型フレーム試験の目的}

2P，4P(control)，6P，6P-DL，4P-2H，4P-SW の 6 シリーズの 試験（図 1）を行うことで, 様々な設計条件をパラメータとする木 質ラーメンフレームの構造性能を確認する。6 シリーズの門型フレ ームについて, フレームの荷重一層間変形角関係（以下， $P^{-} Y$ 関係） と各接合部の $M-\theta$ 関係との関係について考察する。

比較は，スパンをパラメータとした比較 $(2 \mathrm{P}, 4 \mathrm{P}, 6 \mathrm{P})$, 鉛直荷 重の有無による比較（6P, $6 \mathrm{P}-\mathrm{DL})$, 層高をパラメータとした比較

$(4 \mathrm{P}, 4 \mathrm{P}-2 \mathrm{H})$, 梁上耐力壁の有無による比較 $(4 \mathrm{P}, 4 \mathrm{P}-\mathrm{SW})$ の 4 つのパラメータについて行う。

\section{2 門型フレーム試験の試験方法}

図 1 に示す 6 シリーズの試験を各 3 体ずつ行った。6 シリーズの 試験体の使用材料（表 1）は全て共通である。本試験は設計条件を パラメータとする比較を行うことが目的であるので，材料によるば らつきを抑制するために, 梁材, 柱材, 引きボルトは同一ロットの 材を用いた。梁柱接合部、柱脚接合部はともに引きボルト式接合部 (図 2) とし、6 シリーズの試験体で全て共通である。破壊モード によるばらつきを無くすために, せん断長さ（梁木口から座掘まで の長さ）を $300 \mathrm{~mm}$ と大きめにして, 破壊モードを, 脆性的な木部 のせん断破壞ではなく, 勒性のある引きボルトの破断に誘導した。 門型フレーム試験, 梁柱接合部試験, 柱脚接合部試験の全ての試験 体で，引きボルトの軸力を測定するために設置したセンターホール 型ロードセルを用いて, 初期軸力を $5 \mathrm{kN}$ に管理して試験を行った。

$2 \mathrm{P}, 4 \mathrm{P}$ (control)，6P，4P-2H は, 図 1 に示すスパンと層高の試 験体である。シリーズ名のスパン寸法は, $1 \mathrm{P}=910 \mathrm{~mm}$ とし, 柱外 面より $60 \mathrm{~mm}$ (壁厚寸法の $1 / 2$ ) 内側を壁芯として算定した (図 3)。

6P-DL の試験体は 6P の梁に鉛直荷重を載架したものである。鉛 直荷重は $3.0 \mathrm{kN}$ の鉄骨ブロック 4 個を吊り下げた。内側の 2 個は $606 \mathrm{~mm}$ ピッチ 2 か所で支持し, 端部の 2 個は梁柱接合部と干涉す るため 1 か所で吊り下げた (図 1 )。この荷重を等分布荷重に単純に 均して概算すると, ラーメン梁の荷重負担幅を $910 \mathrm{~mm}$ と仮定した 場合の約 $2.4 \mathrm{kN} / \mathrm{m}^{2}$ の設計荷重(Design Load) に相当する。この荷重 は, 用途を店舗とした場合の固定荷重 $1.1 \mathrm{kN} / \mathrm{m}^{2}$, 積載荷重 $1.3 \mathrm{kN} /$ $\mathrm{m}^{2}$ (建築基準法施行令 85 条の地震力計算用）程度を想定したもの であり、ALC 版を用いた遮音床程度の床仕様を想定したものである。

4P-SW の試験体は 4P の門型フレーム架構の上部に 1P の耐力壁 2 枚を載せたものである。耐力壁の仕様は, 幅 $910 \mathrm{~mm} \times$ 高さ $2900 \mathrm{~mm}$, 筋かい $45 \mathrm{~mm} \times 105 \mathrm{~mm}$ 構造用 LVL100E，筋かい金物は 壁倍率 2 倍用ボックス金物, 座屈防止用として筋かいと同材を横方 向 2 段で設置した。4P-SW の試験体の梁上耐力壁 $(3$ 体 $\times 2$ 枚 $=6$ 枚）の試験結果を用いて算定した耐力壁の短期基準せん断耐力は, $14.34 \mathrm{kN} / \mathrm{m}$ （壁倍率 7.32 倍 $/ \mathrm{m}$ ) であった。この算定にあたっては, 木質構造において一般に用いられる完全弾塑性モデルによる評価方 法 5)に準じて行ったが，下部の門型フレームが先行破壊（図 4）す るため $\mathrm{Pu} \times(0.2 / \mathrm{Ds})$ の指標は除いた。また, 本試験の梁上耐力壁の 構造性能を確認するのが目的であるため, ばらつき係数は乗じない で 6 枚の平均值とした。

試験方法を図 3 に示寸。加力は梁の中心 (4P-SW は梁上耐力壁上 部の梁の中心 1 か所で加力) で, $1 / 450,1 / 300,1 / 200,1 / 150,1 / 100$,

1/75, 1/50, $1 / 30$ を正負交番 3 回繰り返しで行い, 最後は左方向に 引き倒した。本試験の加力方向は，一般的な座標軸とは反対になる が，左方向を正方向と定義する（図 3)。変位計は、フレーム全体の 挙動を測定するためのものは図 3 に記載した。接合部には図 5 の接 合部試験の試験方法に示した変位計と同様の変位計を設置して、門 型フレーム試験の各接合部の $M-\theta$ 関係などを測定した。また, 梁材, 柱材の負担モーメント，負担軸力を算定するために，各シリーズの 3 体目のみに，ひずみゲージを設置した。

\section{3 接合部試験の目的}

木質ラーメン構造の設計を行うさいに, 接合部の $M-\theta$ 関係を接合 部試験または計算により算定して, フレームの数值計算を行うこと が多い。また，接合部試験により $M-\theta$ 関係を算定した場合は，接合 部試験の時のモーメント $M$ ・軸力 $N$ ・ せん断力 $Q$ の複合応力の状 態と, 実際に用いるフレームにおける応力状態が異なる場合が多い。

表 1 試験体の仕様

\begin{tabular}{ll}
\hline \multicolumn{1}{c}{ 部位 } & \multicolumn{1}{c}{ 材料・寸法 } \\
\hline \multirow{2}{*}{ 柱 } & $\begin{array}{l}\text { オウシュウアカマツ対象異等級構成集成材 } \\
\text { E105-F300、120mm×390mm }\end{array}$ \\
\hline 梁 & $\begin{array}{l}\text { オウシュウアカマツ対象異等級構成集成材 } \\
\text { E105-F300、120mm×450mm }\end{array}$ \\
\hline 引きボルト & M16、SNR400 \\
\hline 柱座金 & $80 \mathrm{~mm} \times 80 \mathrm{~mm} \times 9 \mathrm{~mm}$ \\
\hline 梁座金 & $54 \mathrm{~mm} \times 54 \mathrm{~mm} \times 9 \mathrm{~mm}$ \\
\hline
\end{tabular}

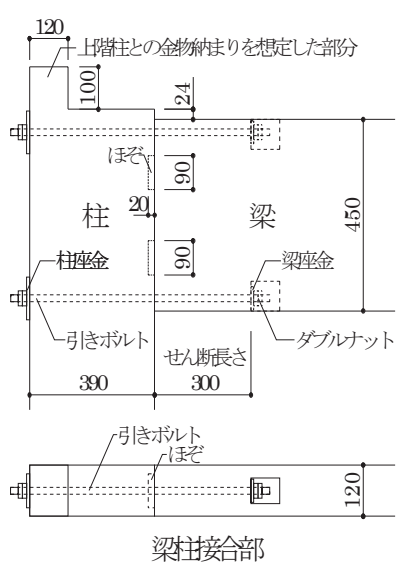

図 2 接合部の仕様

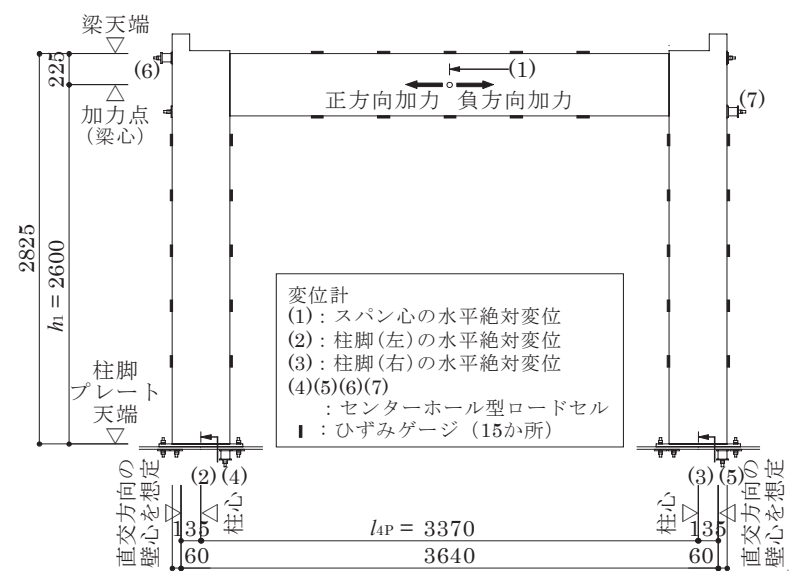

図 3 門型フレーム試験の試験方法 (4P(control)の場合) 
本研究では, 門型フレーム試験と同仕様の接合部の試験体による 梁柱接合部試験 $\mathrm{B} 120$, 柱脚接合部試験 $\mathrm{C} 120$ を行い, 門型フレー ム試験の 各接合部の $M-\theta$ 関係と接合部試験の $M-\theta$ 関係の比較をし て, 門型フレーム試験の各接合部において, $N \cdot Q$ の応力が $M-\theta$ 関 係に与える影響の推定を行う。

また, 接合部のせん断力の影響について検討するために, せん断 スパンをパラメータとした梁柱接合部試験 B 105, B 105 s を行った。

\section{4 接合部試験の試験方法}

梁柱接合部試験 B120, 柱脚接合部試験 $\mathrm{C} 120$ は各 6 体, 梁柱接 合部試験 B105, B105s は各 3 体の試験を行った。梁柱接合部試験 $\mathrm{B} 120$, 柱脚接合部試験 $\mathrm{C} 120$ は, 試験体の使用材料（表 1), 引き ボルト式接合部の仕様 (図 2) とも門型フレーム試験と同様である。 梁柱接合部試験 B105, B105s は, 部材断面が柱 $105 \mathrm{~mm} \times 390 \mathrm{~mm}$, 梁 $105 \mathrm{~mm} \times 450 \mathrm{~mm}$ であり, その他仕様は B120 と同仕様である。 門型フレーム試験の各接合部との比較を行うことが目的であるので, 梁材, 柱材, 引きボルトは, 門型フレーム試験に用いた材と同一ロ ットの材を用いた。

梁柱接合部試験の試験仕様を表 2 , 試験方法を図 5 に示す。B 120 , C120, B105 の加力点は門型フレーム試験 $4 \mathrm{P}$ の梁の反曲点長比 0.5 を想定した点とした。せん断スパンをパラメータとした B $105 \mathrm{~s} の$ 加 力点は B105 の半分とした。加力スケジュールは, 1/450, 1/300, $1 / 200,1 / 150,1 / 100,1 / 75,1 / 50,1 / 30$ を正負交番 3 回繰り返し で行い, 最終加力は両方向とも加力用ジャッキのストロークいっぱ いまで加力を行った。本試験の加力方向は, 一般的な座標軸とは反 対になるが，左方向を正方向と定義する（図 5)。梁柱接合部試験は $\mathrm{L}$ 字型の試験体であるため, 正方向加力と負方向加力では構造性能 が異なり, 正負非対称となる。そのため両方向の構造性能を確認寸 ることとした。しかし、試験場の加力用ジャッキのストロークの関 係で両方向の破断までの加力を行うことはできなかった。そこで加 力用ジャッキのストロークの中心を初期位置として, 両方向とも 1/8rad まで加力を行った。以前に行った同様の試験では $1 / 6 \mathrm{rad}$ 程 度で引きボルト破断が起こったことから, 本試験でも同程度の回転 角で破壊が起こると推察される。また, 試験体の柱・梁材は $3 \mathrm{~m}$ 材 を用いて, 材の両側に仕口を作り，1組で 2 回の試験を行った。

柱脚接合部試験の試験仕様を表 2 , 試験方法を図 5 に示寸。試験 体数は 6 体とした。加力点は門型フレーム試験 $4 \mathrm{P}$ の柱の反曲点高 比 0.5 を想定した点とした。加力スケジュールは, $1 / 450,1 / 300$, $1 / 200,1 / 150,1 / 100,1 / 75,1 / 50,1 / 30$ を正負交番 3 回繰り返し で行い, 最終加力は正方向に引き切りとした。試験体は材の両側に 仕口を作り, 1 組の材で 2 回の試験を行った。

表 2 接合部試験の仕様

\begin{tabular}{|c|c|c|c|}
\hline 試験体 & $\begin{array}{c}\text { 部材断面 } \\
(\mathrm{mm})\end{array}$ & $\begin{array}{l}\text { 接合部フェイスと } \\
\text { 加力点の距離 }(\mathrm{mm})\end{array}$ & 試験体数 \\
\hline B 120 & $\begin{array}{l}\text { 柱: } 120 \times 390 \\
\text { 梁 : } 120 \times 450\end{array}$ & 1490 & 6体 \\
\hline $\mathrm{C} 120$ & 柱 : $120 \times 390$ & 1300 & 6体 \\
\hline B 105 & $\begin{array}{l}\text { 柱 : } 105 \times 390 \\
\text { 梁 : } 105 \times 450\end{array}$ & 1490 & 3体 \\
\hline B $105 \mathrm{~s}$ & $\begin{array}{l}\text { 柱 : } 105 \times 390 \\
\text { 梁 : } 105 \times 450\end{array}$ & 745 & 3体 \\
\hline
\end{tabular}

\section{3. 試験結果}

\section{1 門型フレーム試験の試験結果}

各シリーズの試験結果の試験体 3 体の包絡曲線とバイリニア曲線 の平均を図 6 に示寸。シリーズどうしの試験結果の比較を行うため に, 試験結果の包絡線をバイリニア置換した。バイリニア置換は全 シリーズに共通の方法として以下の(1)から (6)の手順で行った。(1)降 伏点 $\left(y_{y}, P_{y}\right)$ を，木質構造において一般に用いられる完全弾塑性モデ ルの作成方法 5) により決定する。(2)原点 $(0,0)$ と降伏点を結んだ直線 I の勾配を初期剛性 $K_{1}$ と寸る。(3)包絡線上の $0.4 Y_{\text {max }}$ から $0.9 Y_{\text {max }}$ までの最小二乗近似直線を直線 II とし, その勾配を 2 次剛性 $K_{2}$ と する。(4)直線 I と直線 II $の$ 交点を仮想降伏点 $\left(y_{v}, P_{v}\right)$ とする。(5)最大 荷重点の層間変形角を $Y_{u}$ とする。(6) $\mathrm{x}=Y_{u}$ と直線 II の交点を終局点 $\left(Y_{u}, P_{u}\right)$ とする。

各シリーズの試験結果のバイリニア特性值の平均值一覧を表 3 に 示す。 $2 \mathrm{P}$ の終局点変形角の変動係数が $0.24,2$ 次剛性の変動係数が 0.20 と大きな值となった。2Pの 1 体目のみが 0.066rad（1/15rad） で梁柱接合部（右）が梁木口のせん断破壊（図 7）となり，他の 17 体は想定通りのボルト破断となった。破壊モードの違いにより終局 点変形角がばらついたためと考えられる。2P の終局点変形角以外で は, それぞれのシリーズ内では, 剛性, 降伏点, 終局点ともに変動 係数は 0.14 以下となり, 大きなばらつきは無かった。

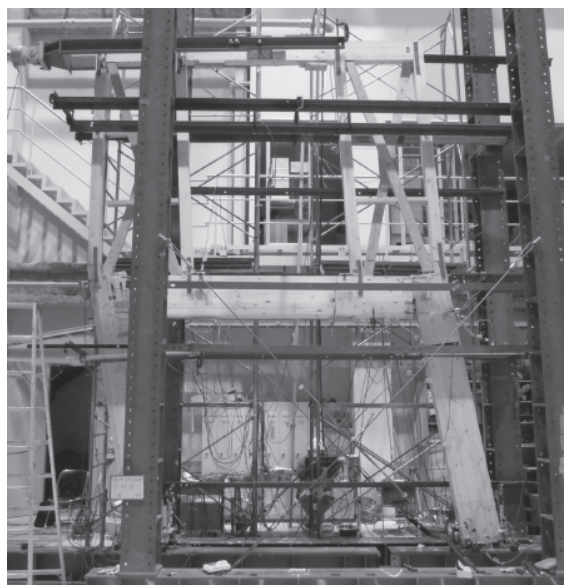

図 4 終局時(約 1/10rad)の $4 \mathrm{P}-\mathrm{SW}$

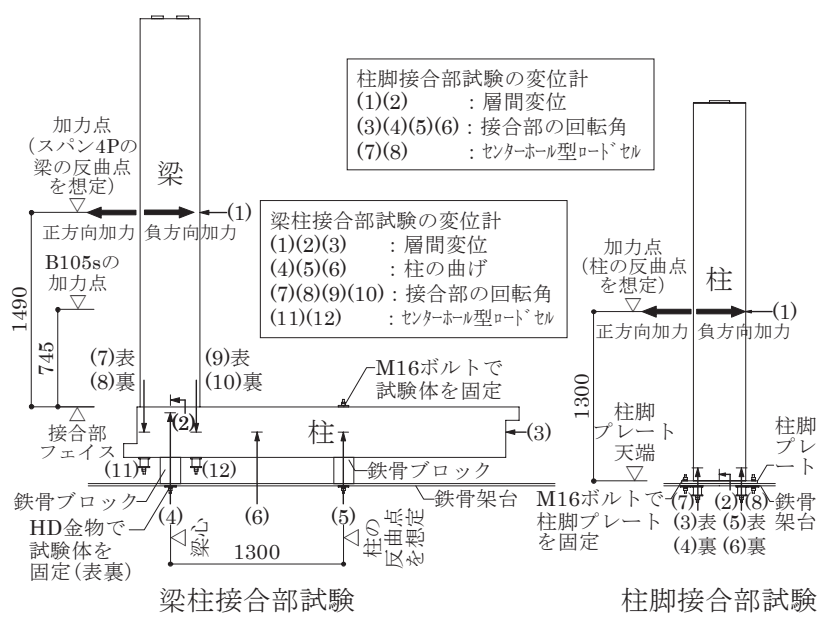

図 5 接合部試験の試験方法 


\section{2 接合部試験の試験結果}

門型フレーム試験の各接合部との比較のために, B120, C120の 試験結果の包絡曲線のバイリニア置換（表 4, 図 8）を行った。モ ーメントは，景山ら 1)の提案する接合部フェイスの位置（図 5）で 算定した。梁柱接合部のバイリニア置換は、門型フレーム試験と同 様の方法で行った。柱脚接合部のバイリニア置換は, 以下の(1)から (6)の手順で行った。(1)包絡線上の $0.1 M_{\max }$ から $0.6 M_{\max }$ までの最小 二乗近似直線を直線 I とする。(2)包絡線上の $0.2 \theta_{M \max }$ から $0.8 \theta_{M \max }$ までの最小二乗近似直線を直線 II とし，その勾配を 2 次剛性 $K_{2}$ と する。(3)直線 I と直線 II の交点を通り $\mathrm{x}$ 軸に平行な直線を直線 III と し, 包絡線と直線III の交点を降伏点 $\left(\theta_{y}, M_{y}\right)$ と寸る。(4)原点 $(0,0)$ と降 伏点を通る直線を直線IV とし, その勾配を初期剛性 $K_{1}$, 直線 IV と直 線 II の交点を仮想降伏点 $\left(\theta_{v}, M_{V}\right)$ とする。(5)最大モーメント点の回転 角を $\theta_{u}$ とする。 $6 \mathrm{y}=\theta_{u}$ と直線 II の交点を終局点 $\left(\theta_{u}, M_{u}\right)$ とする。

破壊モードは，梁柱接合部試験 B120 は全試験体で想定通り破壊 なし，柱脚接合部試験 $\mathrm{C} 120$ も全試験体で想定通り引きボルト破断 となった。バイリニア特性值には大きなばらつきは無かった。

梁柱接合部の加力方向の正負非対称の比較（表 4）は，正方向の 方が，初期剛性は 0.91 倍と低くなったが，降伏モーメントは 1.08 倍， 2 次剛性は 1.30 倍と高くなった。柱脚接合部は梁柱接合部よ り，初期剛性は低いが，降伏モーメントと 2 次剛性は高くなった。 接合部のせん断力の影響を検討するために，せん断スパンをパラ メータとした梁柱接合部試験 B105, B105s の $M-\theta$ 関係, せん断力 一梁と柱の相対変位の関係 (以下, $Q-\delta$ 関係) をバイリニア置換 (図 8）した。 $M-\theta$ 関係は, せん断スパンの短い B105s の方が, 初期剛 性が 0.80 倍，降伏モーメントが 0.92 倍，2 次剛性は 0.77 倍と低く なった。Q- $\delta$ 関係は, B $105 \mathrm{~s}$ の方が, 初期剛性が 1.46 倍, 降伏荷重 が 1.73 倍, 2 次剛性は 1.24 倍と高くなった。破壊モードは，(試験 体 3 体） $\times$ （正・負方向の 2 か所） $=6$ か所のうち, 2 か所で梁木 口のせん断破壊（図 7）となった。他は引きボルト破断となった。
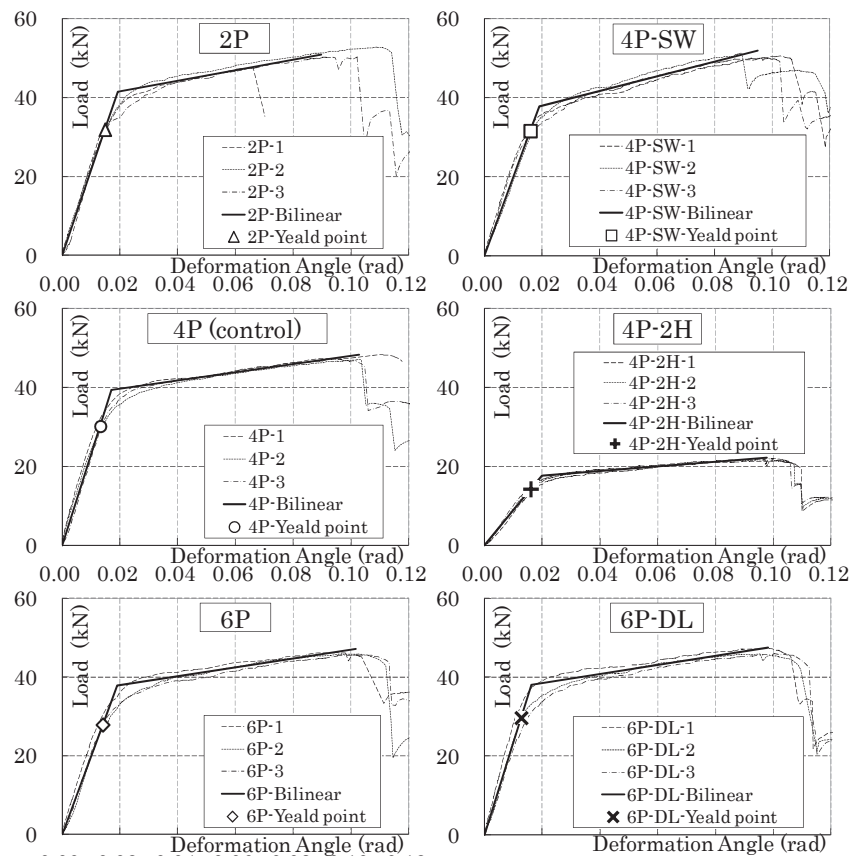

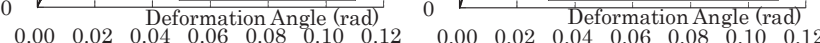

図 6 試験結果の包絡曲線とバイリニア曲線
表 3 門型フレーム試験のバイリニア特性值の平均値一覧

\begin{tabular}{|c|c|c|c|c|c|c|c|c|}
\hline \multirow{2}{*}{$\begin{array}{l}\text { 試験 } \\
\text { シリーズ }\end{array}$} & \multicolumn{2}{|c|}{ 降伏点 } & \multicolumn{2}{|c|}{ 仮想降伏点 } & \multicolumn{2}{|c|}{ 終局点 } & \multirow{2}{*}{$\begin{array}{c}\text { 初期剛性 } \\
K_{1} \\
(\mathrm{kN} \cdot \mathrm{mrad})\end{array}$} & \multirow{2}{*}{$\begin{array}{c}2 \text { 次岡性 } \\
K_{2} \\
(\mathrm{kN} \cdot \mathrm{m} \text { rad })\end{array}$} \\
\hline & $\begin{array}{c}\gamma_{y} \\
(\mathrm{rad})\end{array}$ & $\begin{array}{c}P_{y} \\
(\mathrm{kN} \cdot \mathrm{m})\end{array}$ & $\begin{array}{c}\gamma_{v} \\
(\mathrm{rad})\end{array}$ & $\begin{array}{c}P_{v} \\
(\mathrm{kN} \cdot \mathrm{m})\end{array}$ & $\begin{array}{c}\gamma_{u} \\
(\mathrm{rad})\end{array}$ & $\begin{array}{c}P_{u} \\
(\mathrm{kN} \cdot \mathrm{m})\end{array}$ & & \\
\hline \multirow{2}{*}{$2 \mathrm{P}$} & 0.0148 & 31.88 & 0.0193 & 41.47 & 0.0897 & 50.85 & 2152 & 139 \\
\hline & $(0.04)$ & $(0.01)$ & $(0.07)$ & $(0.04)$ & $(0.24)$ & $(0.05)$ & $(0.03)$ & $(0.2)$ \\
\hline \multirow{2}{*}{ 4P(control) } & 0.0132 & 30.24 & 0.0172 & 39.32 & 0.1027 & 4832 & 2299 & 106 \\
\hline & $(0.12)$ & $(0.05)$ & $(0.08)$ & $(0.01)$ & $(0.09)$ & $(0.02)$ & $(0.09)$ & $(0.09)$ \\
\hline \multirow{2}{*}{$6 \mathrm{P}$} & 0.0140 & 27.90 & 0.0190 & 37.84 & 0.1017 & 47.05 & 2007 & 111 \\
\hline & $(0.12)$ & $(0.01)$ & $(0.1)$ & $(0.04)$ & $(0.06)$ & $(0.01)$ & $(0.12)$ & $(0.11)$ \\
\hline \multirow{2}{*}{ 6P-DL } & 0.0128 & 29.72 & 0.0164 & 38.09 & 0.0981 & 47.42 & 2345 & 114 \\
\hline & $(0.09)$ & $(0.04)$ & $(0.11)$ & $(0.03)$ & $(0.03)$ & $(0.01)$ & $(0.14)$ & $(0.07)$ \\
\hline \multirow{2}{*}{$4 \mathrm{P}-2 \mathrm{H}$} & 0.0161 & 14.34 & 0.0198 & 17.72 & 0.097 & 2216 & 897 & 57 \\
\hline & $(0.1)$ & $(0.02)$ & $(0.06)$ & $(0.02)$ & $(0.03)$ & $(0.01)$ & $(0.08)$ & $(0.05)$ \\
\hline \multirow{2}{*}{ 4P-SW } & 0.0160 & 31.60 & 0.0191 & 37.78 & 0.0950 & 51.89 & 1984 & 187 \\
\hline & $(0.12)$ & $(0.08)$ & $(0.09)$ & $(0.03)$ & $(0.07)$ & $(0.01)$ & $(0.06)$ & $(0.05)$ \\
\hline
\end{tabular}

※()内の数字は変動係数

表 4 接合部試験 B120, C120 のバイリニア特性值の平均値一覧

\begin{tabular}{ccccccccc}
\hline & \multicolumn{2}{c}{ 降伏点 } & \multicolumn{2}{c}{ 仮想降伏点 } & \multicolumn{2}{c}{ 終局 点 } & 初期剛性 & 2次剛性 \\
試験体 & $\begin{array}{c}\theta_{y} \\
(\mathrm{rad})\end{array}$ & $\begin{array}{c}M_{y} \\
(\mathrm{kN} \cdot \mathrm{m})\end{array}$ & $\begin{array}{c}\theta_{v} \\
(\mathrm{rad})\end{array}$ & $\begin{array}{c}M_{v} \\
(\mathrm{kN} \cdot \mathrm{m})\end{array}$ & $\begin{array}{c}\theta_{u} \\
(\mathrm{rad})\end{array}$ & $\begin{array}{c}M_{u} \\
(\mathrm{kN} \cdot \mathrm{m})\end{array}$ & $\begin{array}{c}K_{l} \\
(\mathrm{kN} \cdot \mathrm{mrad})\end{array}$ & $\begin{array}{c}K_{2} \\
(\mathrm{kN} \cdot \mathrm{mrad})\end{array}$ \\
\hline \multirow{2}{*}{$\mathrm{B} 120$ (負力向) } & 0.0082 & 16.76 & 0.0125 & 25.39 & 0.1250 & 31.45 & 2064 & 54 \\
& $(0.1)$ & $(0.06)$ & $(0.11)$ & $(0.02)$ & $(0)$. & $(0.02)$ & $(0.14)$ & $(0.08)$ \\
\hline \multirow{2}{*}{$\mathrm{B} 120$ (正力向) } & 0.0097 & 18.02 & 0.0136 & 25.39 & 0.1250 & 33.15 & 1884 & 70 \\
& $(0.11)$ & $(0.06)$ & $(0.13)$ & $(0.03)$ & $(0)$. & $(0.04)$ & $(0.12)$ & $(0.17)$ \\
\hline \multirow{2}{*}{$\mathrm{Cl} 20$} & 0.0144 & 23.16 & 0.0147 & 23.71 & 0.1033 & 30.77 & 1615 & 86 \\
& $(0.06)$ & $(0.01)$ & $(0.06)$ & $(0.02)$ & $(0.03)$ & $(0.01)$ & $(0.06)$ & $(0.07)$ \\
\hline
\end{tabular}

※( )内の数字は変動係数

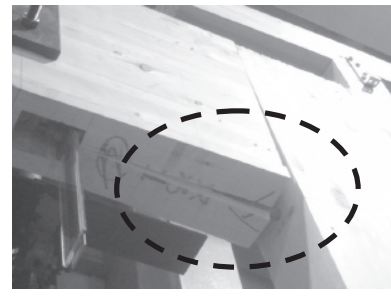

門型フレーム試験 $2 \mathrm{P}$

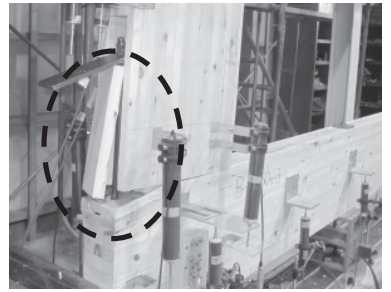

梁柱接合部試験 B105s
図 7 梁柱接合部の梁木口のせん断破壊
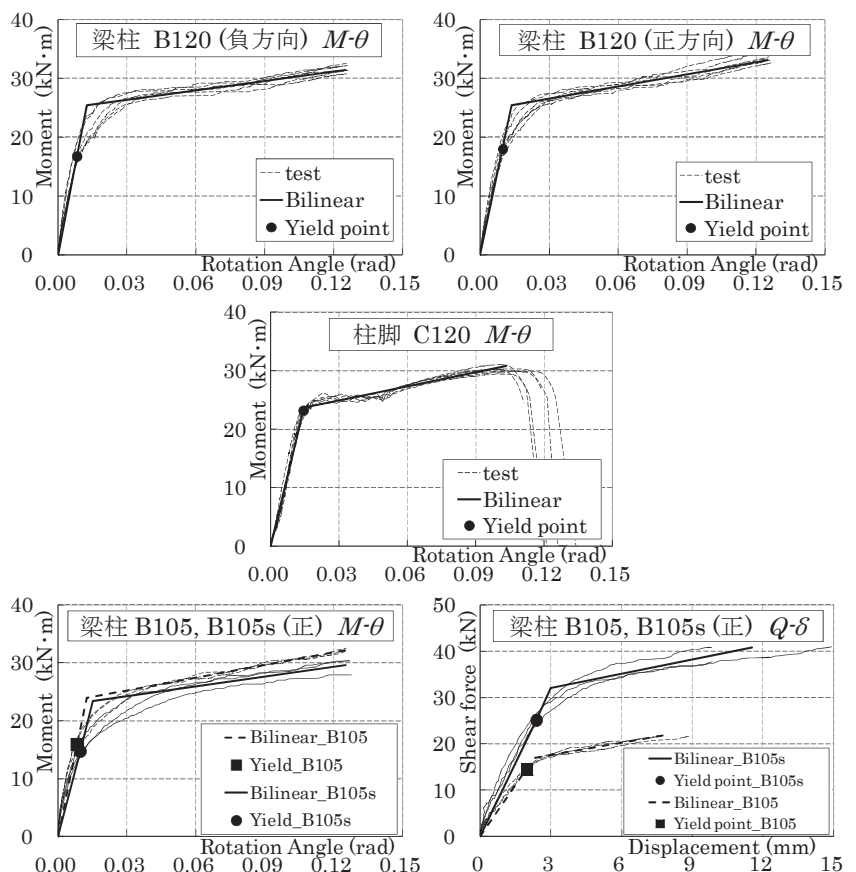

図 8 接合部試験の包絡曲線とバイリニア曲線 

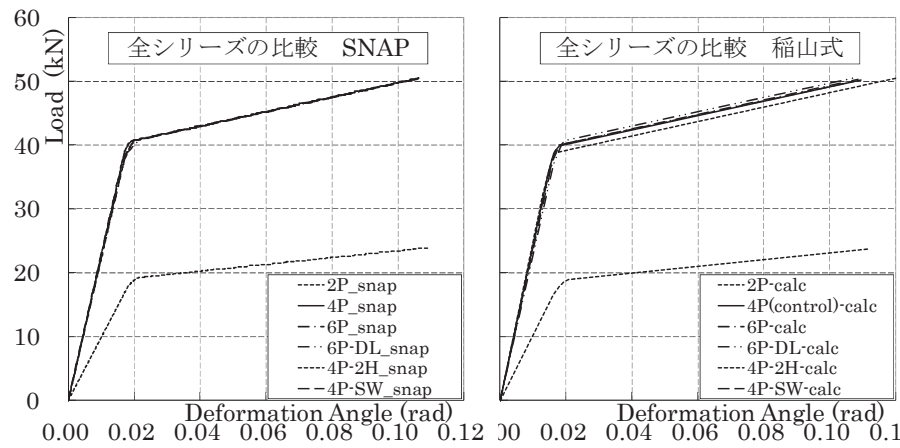

図 9 門型フレームの $P-Y$ 関保
0.040 .06 SNAP

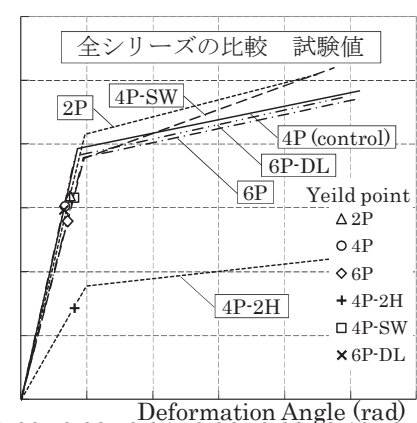

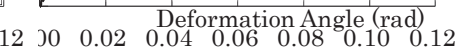
稲山式の数值計算, 試験值



図 10 構造芯モデル（4P の場合）

\section{4. 門型フレームのP- $y$ 関係ついての考察 (その 1)}

考察は 3 章に渡って行う。この 4 章で, 門型フレームの $P-Y$ 関係 についての問題提起を行う。次の 5 章で, 接合部の $M-\theta$ 関係ついて の考察を行う。最後の 6 章で, 門型フレームのP $P-Y$ 関係について, 5 章の結果を用いながら 4 章で提起した問題などの考察を行う。

門型フレームのP- $Y$ 関係の試験值のバイリニア曲線についての比 較をするために, 2 種類の方法で数值計算を行った。解析モデル (図 10）は共通で, 梁と柱を線材置換して, この構造芯の交点に回転バ ネを設けたモデルとした（以下，構造芯モデル)。景山ら2）は木質 ラーメンフレームの数值計算の解析モデルとして, 接合部の剛域を 考慮した剛域モデルを提案しているが, ここでは比較対象として, 現在一般的に数值計算の解析モデルとして用いられている構造芯モ デルとした。回転バネは表 4 の值を用いた。ただし, 梁柱接合部は 接合部フェイスの值なので, 構造芯の交点の值に換算して用いた。

1 つ目は, 弾塑性フレーム解析ソフト SNAP（構造システム製） を用いて, 強制変位増分による 1 方向非線形解析で, せん断変形や P- $\Delta$ 効果による変形を考慮して数值計算を行った。せん断変形やP- $\Delta$ 効果による変形はほとんどなかった。主な変形の要素は, 部材の曲 げ変形と接合部の回転バネによる変形である。 $4 \mathrm{P}-2 \mathrm{H}$ 以外の $2 \mathrm{P}$, 4P，6P，6P-DL，4P-SW の 5 シリーズは, 仮想降伏点（初期剛性 と 2 次剛性の交点）の付近で若干の違いがあったが, 初期剛性, 仮 想降伏点, 2 次剛性ともほぼ同じ值となった（図 9 左）。

2 つ目は, 稲山の提案した門型フレームの計算式 6) (以下, 稲山 式）により数值計算を行った。主な変形の要素は, SNAP と同様に 部材の曲げ変形と接合部の回転バネによる変形があり, さらに柱脚 に生じる柱軸力の影響を考慮している。 $4 \mathrm{P}-2 \mathrm{H}$ 以外の 5 シリーズ は, 初期剛性, 2 次剛性はほぼ同じ值となったが, 仮想降伏点は異 なる值となった（図 9 中)。仮想降伏点が異なる值となったのは, 柱軸力の影響を考慮したためである。

$4 \mathrm{P}$ で比較すると, 初期剛性と 2 次剛性は SNAP, 稲山式ともに 試験值とほぼ同じ值であったが，仮想降伏荷重は高い值となった。

2 つの方法による数值計算の值と試験值（図 9 右）を, 主に仮想 降伏荷重の值で比較する。比較は, スパンをパラメータとした比較 $(2 \mathrm{P}, 4 \mathrm{P}, 6 \mathrm{P})$, 鉛直荷重の有無による比較 $(6 \mathrm{P}, 6 \mathrm{P}-\mathrm{DL})$, 層高 をパラメータとした比較 $(4 \mathrm{P}, 4 \mathrm{P}-2 \mathrm{H})$, 梁上耐力壁の有無による 比較（4P, $4 \mathrm{P}-\mathrm{SW})$ の 4 つのパラメータについて行う。

スパンの比較では, 仮想降伏荷重の值は, SNAP では $2 \mathrm{P} \fallingdotseq 4 \mathrm{P} \fallingdotseq$ $6 \mathrm{P}$, 稲山式では $2 \mathrm{P}<4 \mathrm{P}<6 \mathrm{P}$, 試験值では $2 \mathrm{P}>4 \mathrm{P}>6 \mathrm{P}$ となった。 SNAP では, 部材の曲げ変形分の差はあるが, グラフから読み取る
ことはできない程度の差であった。稲山式では, フレームの引張側 の柱軸力の影響による柱脚接合部の負担モーメントの低減により, 軸力の大きくなるスパンの短いシリーズほど, 仮想降伏荷重の值の 低下が大きかった。試験結果は稲山式による数值計算と反対の結果 になった。接合部の回転バネ, 部材の曲げ, 柱軸力の影響の 3 つ以 外にフレームの変形に大きな影響を与える要因があると考えられる。 この要因については 6 章で検討する。

鉛直荷重の比較では, 仮想降伏荷重の值は, SNAP では $6 \mathrm{P} \fallingdotseq$ $6 \mathrm{P}-\mathrm{DL}$, 稲山式では $6 \mathrm{P}<6 \mathrm{P}-\mathrm{DL}$, 試験值では $6 \mathrm{P}<6 \mathrm{P}-\mathrm{DL}$, となっ た。試験值と稲山式は同様の傾向であった。稲山式では, フレーム の引張側の柱軸力の影響と鉛直荷重による柱軸力が相殺され，6P よりも $6 \mathrm{P}-\mathrm{DL}$ の方が柱脚接合部の負担モーメントが向上して, 仮想 降伏荷重の值が上がった。この部分においては, 試験体の挙動を上 手く再現していた。しかし、6P，6P-DL ともに初期剛性と仮想降伏 点は、試験值よりも SNAP, 稲山式の值の方が高い值となった。

層高の比較では, 接合部に入力するモーメントは（モーメント） $=($ 負担せん断力 $) \times($ 層高 $) \times($ 反曲点高比 $)$ となるので, 荷重 值が層高に反比例する。この傾向は SNAP, 稲山式ともに試験值と 合っている。ただし $4 \mathrm{P}-2 \mathrm{H}$ の初期剛性と仮想降伏点は、試験值より も SNAP, 稲山式の值の方が高い值となった。

梁上耐力壁の比較では, 2 次剛性の值は SNAP, 稲山式ともに $4 \mathrm{P}$ $\fallingdotseq 4 \mathrm{P}-\mathrm{SW}$ だったが, 試験值では $4 \mathrm{P}<4 \mathrm{P}-\mathrm{SW}$ と異なる結果となった。

\section{5. 接合部の $M-\theta$ 関係ついての考察}

\section{1 材せい寸法の影響}

門型フレーム試験において全シリーズに共通する性質として, 梁 材と柱材の幾何学的関係による接合部の回転角の影響が考えられる。 木質ラーメン構造は, 一般に部材の剛性・強度に比べて, 接合部 の剛性・強度が低い。よって変形の大部分は接合部の変形となる。 部材を剛体, 部材の回転中心を接合部の圧縮端と仮定して, 門型フ レームの変形状態を模式的に描くと, 図 11 に示寸通り, フレーム の圧縮側（左側）の接合部の方が回転角が大きくなる。たとえば, $4 \mathrm{P}$ の試験体寸法の場合, 左柱の回転半径 $=2407 \mathrm{~mm}$ (左柱の左下端 から梁左下端の距離), 右柱の回転半径 $=2825 \mathrm{~mm}$ (右柱の左下端か ら梁右上端の距離）となり, 各節点の水平移動距離はほぼ等しいの で, 接合部の回転角の比は回転半径の比の逆比で近似することがで き, 左側接合部の回転角 /右側接合部の回転角 $\fallingdotseq 2825 / 2407 \fallingdotseq 1.17$ と, 梁柱接合部, 柱脚接合部ともに左側の回転角の方が大きくなる。 門型フレーム試験の全シリーズの接合部の回転角ーフレームの層 
間変形角の関係を, 図 12 に示す。図 12 は各 3 体の試験体のなかか ら代表的な試験体の結果を示した。全シリーズにおいて各 3 体中 2 体以上は同様の傾向を示していた。全シリーズとも, 梁柱接合部で は左側（圧縮側）の方が右側（引張側）よりも回転角が大きくなっ ている。柱脚接合部についても $4 \mathrm{P}-2 \mathrm{H}$ 以外は同様の結果となってい る。図 11 に示した門型フレームの変形の性質が, 試験によって確 認できた。ここで層間変形角を算定する際の高さは, 柱材の下端か ら梁心までの $2600 \mathrm{~mm}$ とした。よって, 部材を剛体, 部材の回転中 心を接合部の圧縮端と仮定すると, 左側の接合部の回転角は層間変 形角よりも大きくなり，右側の接合部の回転角は層間変形角よりも 小さくなると考えられる。しかし, 接合部圧縮側のめり込久変形, 部材の曲げ変形などにより, 接合部の変形角は上記の剛体仮定によ る推定よりも小さい值となった。

圧縮側の方が接合部の回転角が大きいということは, 負担するモ ーメントも大きくなるということである。本試験の門型フレームの 場合は左側が圧縮側となるので，梁柱接合部，柱脚接合部ともに左 側の接合部のモーメント負担が右側よりも大きくなると推察される。

一般的な構造芯モデルによるフレームの数值計算だと圧縮側と引 張側の負担モーメントの偏りは考慮されない。部材長さに対する部 材せいの割合が大きい場合は, 解析モデルの作成にあたって, 部材 せいを考慮する必要があると考えられる。

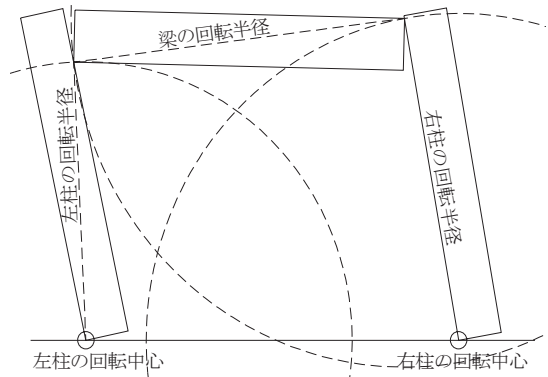

図 11 門型フレームの左右の接合部の回転角の関係
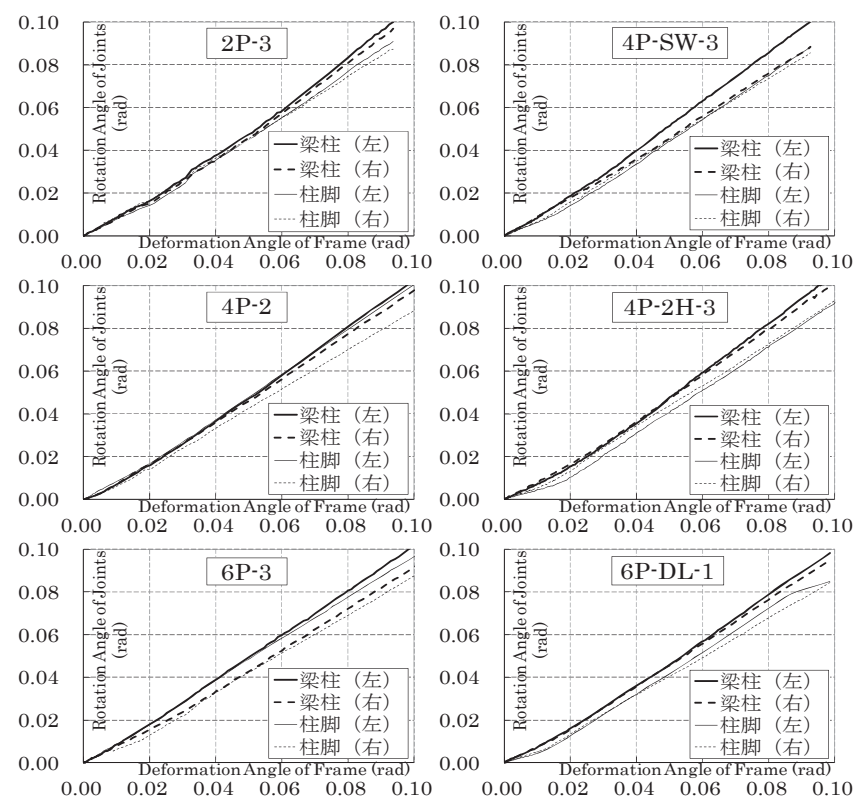

図 12 接合部の回転角ーフレームの層間変形角の関係

\section{2 複合応力の影響}

\subsection{1引きボルト式接合部の抵抗メカニズム}

本試験仕様の引きボルト式接合部の抵抗メカニズムと複合応力の 影響（図 13）について，梁柱接合部で考察を行う。

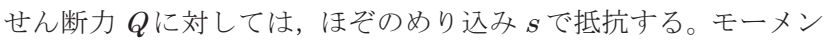
卜，軸力とは，基本的には独立して抵抗するメカニズムとなる。

モーメント $M$ に対しては, 接合部の引張側は, 引きボルトの伸び $t$ で抵抗する。ボルト端部の梁側は，梁座金の繊維方向の等変位め り込み, 柱側は, 柱座金の繊維直交方向の等変位めり込みで抵抗す る。 3 つの直列バネである。圧縮側は, 梁木口の三角形めり込み $c$ で抵抗する。

軸力 $N$ に対しては, モーメントに対する抵抗要素と共用となって いる。軸力は, 引張側と圧縮側の剛性に比例して配分される。モー メントと軸力の複合応力について考慮する必要がある。

引きボルト式接合部の場合, モーメントと軸力に対する抵抗要素 である, 引張バネと圧縮バネは全く別の抵抗要素であり, 独立して いる。この性質は引きボルト式接合部の特徴と言える。

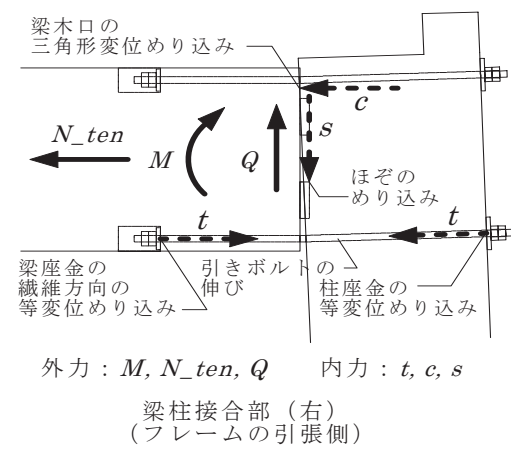

図 13 引きボルト式接合部の抵抗メカニズムと複合応力の影響

\section{2 .2 複合応力の影響の考察方法と複合応力の算定方法}

門型フレーム試験においてシリーズ毎に異なる性質として，各接 合部の複合応力の影響がある。

ここでは, 門型フレーム試験の各接合部の $M-\theta$ 関係に対して軸力 $N$ がどのような影響を与えるか, 門型フレーム試験の各接合部の $M-\theta$ 関係に対してせん断力 $Q$ がどのような影響を与えるか, の 2 点について， $2 \mathrm{P} ， 4 \mathrm{P}, 6 \mathrm{P}, 4 \mathrm{P}-2 \mathrm{H}$, の 4 シリーズで考察を行う。 4P-SW，6P-DL は, 応力状態が複雑なため, 数值計算を併用して接 合部の応力状態の詳細な検討が必要と考えられる。今回の考察から は割愛する。

接合部の $M \cdot N \cdot Q$ の算定を，ひずみゲージの測定を行った各シ リーズ 3 体目の試験值を用いて行う（図 14 図 17）。算定は, 門型 フレーム試験の荷重値, 層間変形角, 接合部の回転角, ひずみゲー ジの值から算定した反曲点の值を用いて, 稲山式 6)により行った。

\subsection{3 軸力 $N$ が接合部の $M-\theta$ 関係に与える影響}

門型フレーム試験の各接合部の $M-\theta$ 関係に対する $N$ の影響の全 シリーズに共通した傾向は，以下のように推察される。

5.2 .1 節で考察した通り, 梁柱接合部の引張側は 3 つの直列バネ, 圧縮側は梁木口による柱一のめり込みバネである。梁の軸力は引張 バネと压縮バネに剛性配分される。弾性域では, 圧縮側と引張側の 

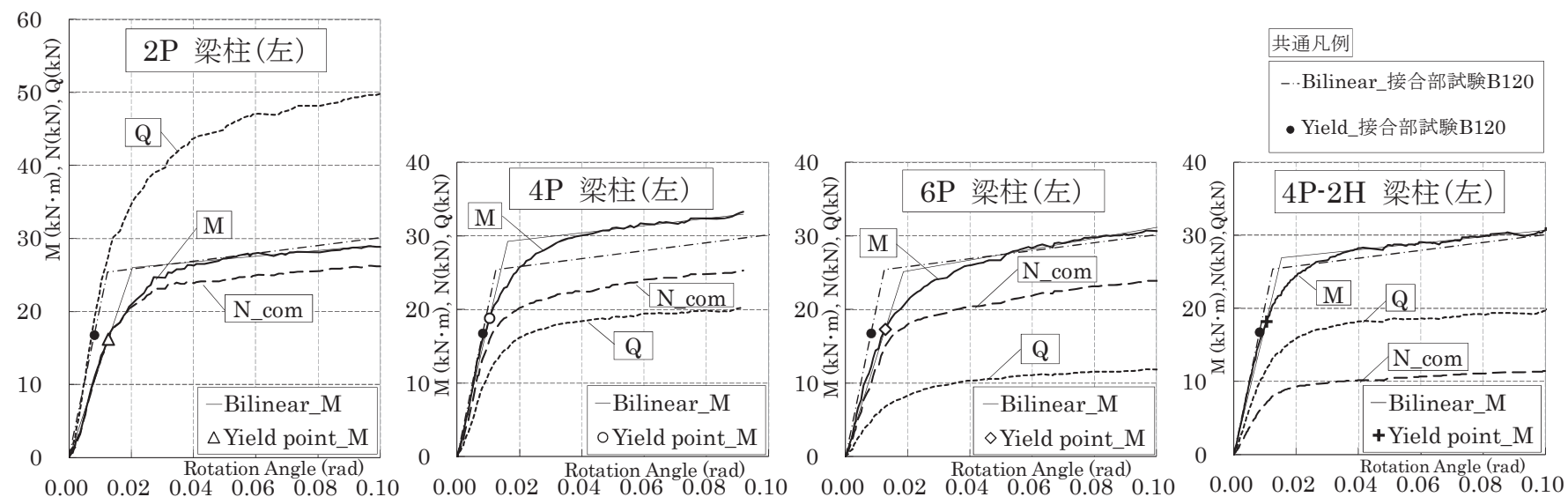

図 14 梁柱接合部 $($ 左・圧縮側 $)$
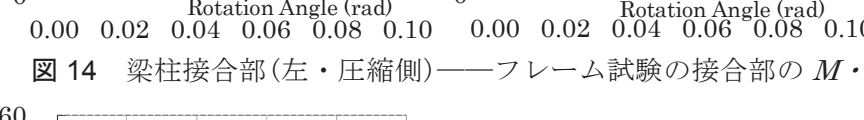

——レーム試験の接合部の $M \cdot N \cdot Q$, およびフレーム試験と接合部試験の接合部の $M \cdot \theta$ 関係の比較
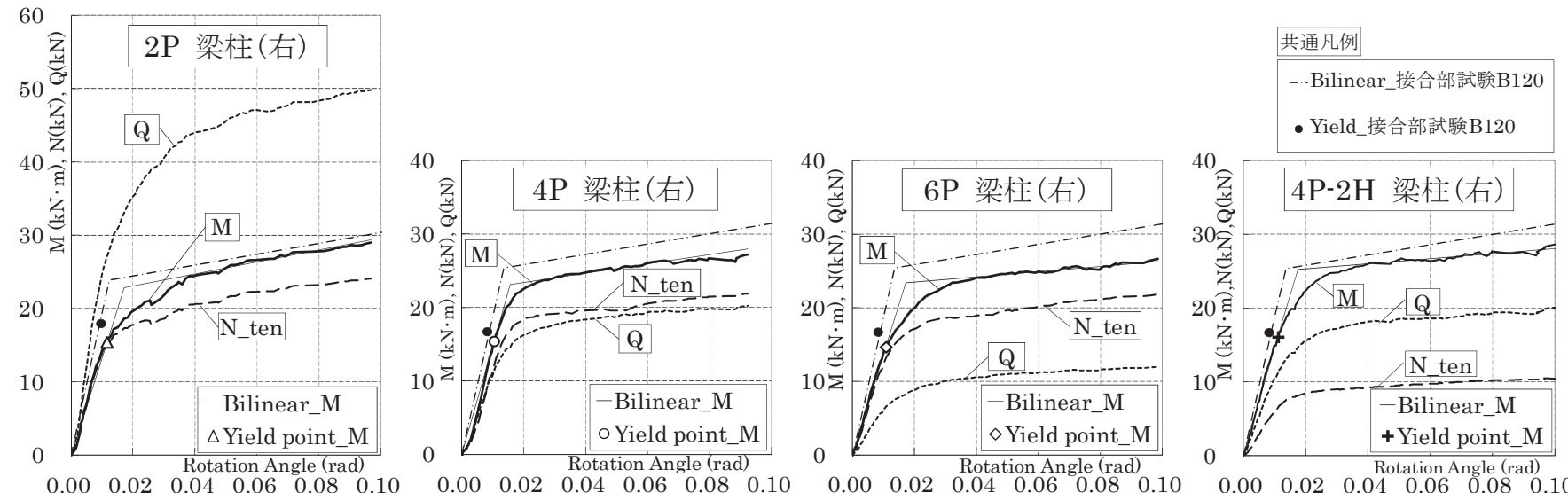

図 15 梁柱接合部 (右・引張側)——レーム試験の接合部の $M \cdot N \cdot Q$, およびフレーム試験と接合部試験の接合部の $M-\theta$ 関係の比較
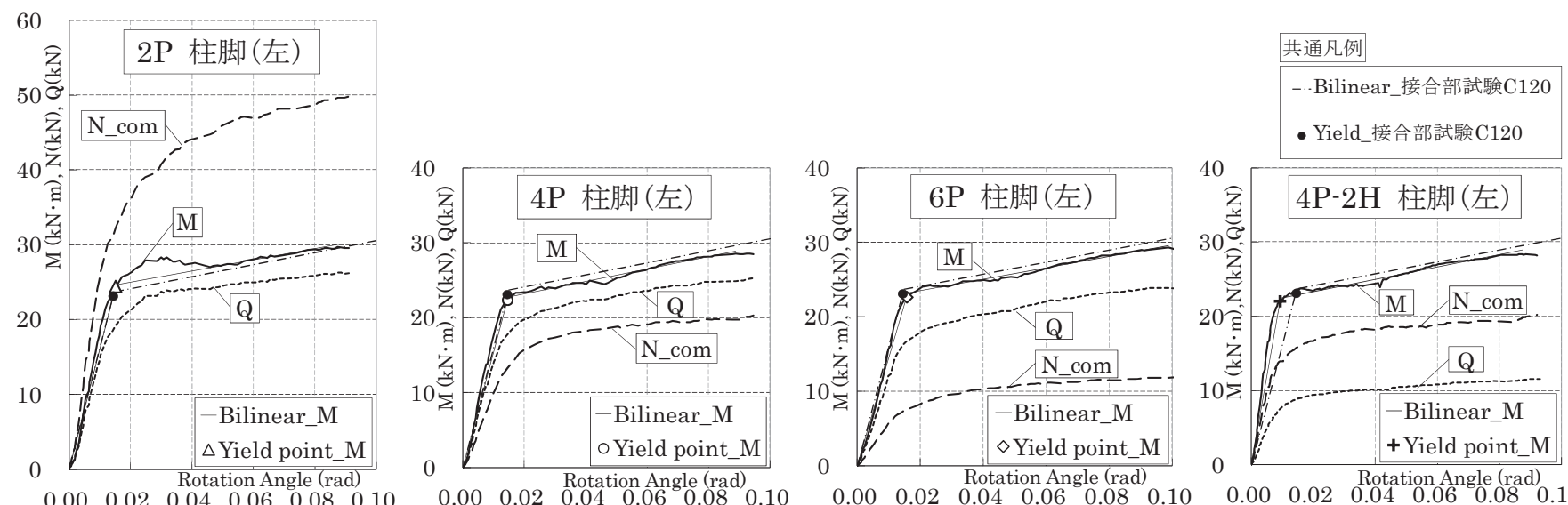

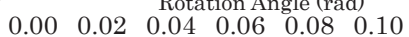

$\begin{array}{llll}0.00 & \text { Rotation Angle (rad) } \\ 0.02 \quad 0.040 .060 .08 & 0.10\end{array}$

図 16 柱脚接合部 (左・圧縮側)——レーム試験の接合部の $M \cdot N \cdot Q$, およびフレーム試験と接合部試験の接合部の $M-\theta$ 関係の比較

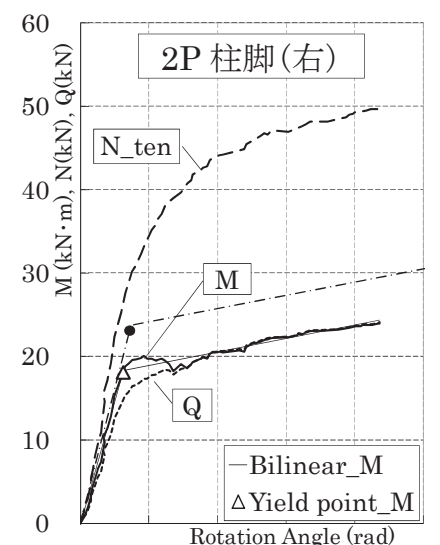

$\begin{array}{llll}0.00 & 0.02 & \begin{array}{l}\text { Rotation Angle (rad) } \\ 0.04\end{array} 0.06 \quad 0.08 \quad 0.10\end{array}$
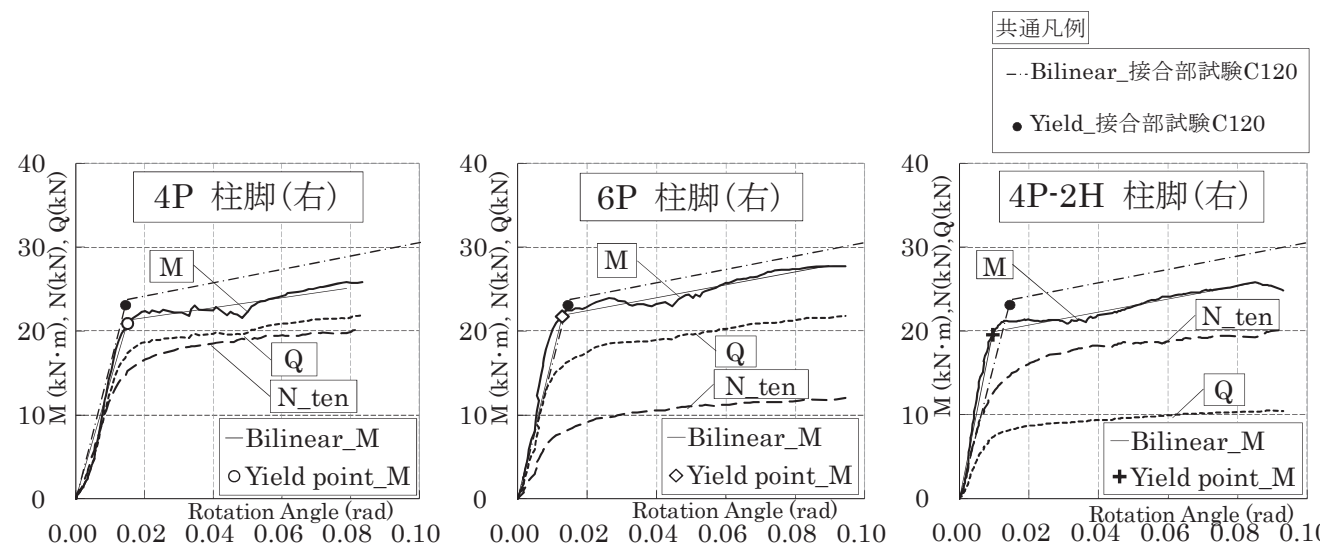

図 17 柱脚接合部 $($ 右・引張側 $)$ 一 フレーム試験の接合部の $M \cdot N \cdot Q$, およびフレーム試験と接合部試験の接合部の $M-\theta$ 関係の比較 
剛性はあまり変わらないので, 梁の圧縮軸力, 引張軸力とも, 初期 剛性にはそれほど影響はないと推察される。塑性域では, 接合部の 変形の大部分は引きボルトの伸びである。接合部の圧縮側のめり込 み変形は変形量が小さいので, 梁の圧縮軸力の大部分は, 接合部の 回転中心に近い接合部の圧縮側に流れると考えられる。そのため, フレームの圧縮側では, 梁の圧縮軸力の影響はほとんどなく, 剛性・ 耐力は接合部試験と同程度になると推察される。一方, 梁の引張軸 力は, 引きボルトの伸びと同方向の力であるため, フレーム試験の 接合部の見かけの耐力は下がる。柱脚接合部も同様である。

以上の推察について, 試験結果を用いて検討を行う。門型フレー ム試験の各接合部の $M-\theta$ 関係に対する $N$ の影響について接合部ご と（図 14 図 17）に, 上記の梁柱接合部, 柱脚接合部に関する推察 について検討する。なお, 図中の $N \_c o m$ は圧縮軸力, N_ten は引 張軸力を表わ寸。梁柱接合部（左・圧縮側）（図 14）は, 全体の傾 向としては上記推察通り, 剛性・耐力ともにフレーム試験の接合部 は接合部試験の接合部とほぼ同程度であった。しかし，2P，6P は フレーム試験の接合部の方が剛性は少し低く, $4 \mathrm{P}$ は耐力が高かった。 梁柱接合部（右・引張側）（図 15）も, 全体の傾向としては上記推 察通り, 剛性はほぼ同じで, 耐力はフレーム試験の接合部が低かっ た。ただし，剛性はフレーム試験の接合部の方が少し低めの值であ った。柱脚接合部（左・圧縮側）（図 16）は，全てのシリーズで上 記の推察の通り, 剛性・耐力ともに接合部試験のものと同程度であ った。ただし，4P-2H の剛性は少し高かった。柱脚接合部（右・ 引張側）（図 17）も, 全てのシリーズで上記の推察の通り, 剛性は 変わらず, 耐力はフレーム試験の接合部の方が低くなった。 $2 \mathrm{P}, 4 \mathrm{P}$, $6 \mathrm{P}$ の比較をすると, スパンの短い方が引張軸力は大きいので, モー メントの低滅が大きくなり, 降伏モーメントは $2 \mathrm{P}<4 \mathrm{P}<6 \mathrm{P}$ の順と なった。全体として上記推察は妥当と考えられるが, 梁柱接合部で は推察とは異なる結果もあった。

梁柱接合部も柱脚接合部と同様に, 引張軸力による $M-\theta$ 関係の低 減が生じるので, 梁柱接合部の設計にあたっては, その点を考慮す る必要があると考えられる。

\subsection{4 せん断力 $Q$ が接合部の $M-\theta$ 関係に与える影響}

5.2.1 節で説明した通り, 基本的に引きボルト式接合部においては, せん断力 $Q$ は接合部に設けたほぞで受けるので，基本的には $M-\theta$ 関係とは独立していると考えられる。

梁柱接合部試験 B 105 とせん断スパンを半分にした B105s との比 較により, $Q$ が $M-\theta$ 関係に与える影響の考察を行う。 $M-\theta$ 関係の剛 性・耐力は, B105s の方が低くなった（図 8)。Qの影響により, $M-\theta$ 関係の剛性・耐力は，ある程度下がると推察される。

梁柱接合部の $Q-\delta$ 関係の剛性・耐力は, $\mathrm{B} 105 \mathrm{~s}$ の方が高くなっ た（図 8)。せん断スパンが短い試験体の方が，同一のせん断力の時 に, 接合部の回転角が小さいので，ほぞ穴とほぞとの接触角度が小 さくなる。接触角度が小さいほど, 接触面積が大きくなるので, 剛 性・耐力は高くなると考えられる。Q- $\delta$ 関係は $\mathrm{B} 105 \mathrm{~s}$ の方が，初期 剛性 1.46 倍・降伏耐力 1.73 倍, 2 次剛性 1.25 倍となった。

せん断スパンは, 初期剛性にも影響を与えている。木質ラーメン の接合部の検討では, 弾性域でも, 回転による幾何学的な部材配置 の変化の影響を考慮する必要がある場合があると考えられる。

本試験では，接合部の破壊性状を勒性のある引きボルトの破断に
誘導するため，梁木口のせん断長さを $300 \mathrm{~mm}$ と大きく設定した。 接合部試験において $\mathrm{B} 105 \mathrm{~s}$ 以外の試験体は全て引きボルトの破断 となった。しかし，B105s は 6 か所のうち 2 か所で梁木口のせん断 破壞（図 7）となった。B105s はせん断力について，見かけの剛性・ 耐力は高いが，終局状態ではせん断力による変位は大きくなる。引 きボルトがボルト穴の中で, 部材の外面方向に力を加えることで, せん断破壊を誘発したと考えられる。

門型フレーム試験でも，2P 1 体目以外の破壊モードは，想定 通り引きボルトの破断だったが， 1 体目の久破壊モードが梁柱 (右) の梁木口のせん断破壊（図 7）となった。これは $2 \mathrm{P}$ の梁柱接合部 の負担せん断力が大きかったためと考えられる。フレーム形状の違 いに基づく応力状態の違いが, 接合部の破壊モードに影響を与えた。

\section{6. 門型フレームのP $P-y$ 関係ついての考察（その 2）}

\section{1 門型フレームの降伏点と各接合部の降伏点についての考察}

門型フレーム試験の各シリーズの 3 体目の包絡線上に, 門型フレ 一ムの降伏点と 5.2 .2 節で算定した各接合部の降伏点をプロットし た（図 18）。表 5 にフレームの降伏点，接合部の降伏点および接合 部降伏時のフレームの層間変形角の関係を示した。

全シリーズにおいて 2 つ目の接合部の降伏点の後で, フレームの 降伏が起こっている。また, 全シリーズで, フレームの引張側であ る梁柱（右）が最初に降伏した。柱脚も右側が先に降伏したのは, $2 \mathrm{P} ， 6 \mathrm{P} ， 4 \mathrm{P}-2 \mathrm{H}$ となり，4 シリーズ中で 3 シリーズだった。

5.1 節の材せい寸法の影響を考慮すると, 左側の方が接合部の回 転角が大きくなるので, 左側の接合部が先に降伏すると考えられる。 3.2 節の梁柱の正負非対称の比較を考慮すると, 負方向（門型フレ 一ムの左側）の方が，降伏モーメントが低いので，左側の接合部が 先に降伏寸ると考えられる。一方， 5.2 節の複合応力の影響を考慮 すると, 引張軸力の影響により, 右側が先に降伏すると考えられる。

試験では右側の接合部が先に降伏しているので，フレームの各接 合部の降伏順序の決定においては，上記の材せい寸法の影響，正負 非対称, 複合応力の影響の 3 つの要素のうち, 複合応力の影響が大 きいと考えられる。

表 5 フレームの降伏点と接合部の降伏点の関係

\begin{tabular}{|c|c|c|c|c|c|c|c|c|}
\hline \multirow{2}{*}{ 試験体 } & \multicolumn{2}{|c|}{$\begin{array}{c}\text { フレームの } \\
\text { 降伏 }\end{array}$} & \multirow{2}{*}{ 接合部 } & \multirow{2}{*}{$\begin{array}{l}\text { 降伏 } \\
\text { 順序 }\end{array}$} & \multirow{2}{*}{\multicolumn{2}{|c|}{$\begin{array}{c}\text { 接合部降伏時 } \\
\text { のフレムム } \\
\text { 層間変形角 } \\
\gamma_{\theta y} \\
(\mathrm{rad}) \\
\end{array}$}} & \multicolumn{2}{|c|}{ 接合部の降伏点 } \\
\hline & $\begin{array}{c}\gamma_{y} \\
(\mathrm{rad})\end{array}$ & $\begin{array}{c}P_{y} \\
(\mathrm{kN}) \\
\end{array}$ & & & & & $\begin{array}{c}\theta_{y} \\
(\mathrm{rad}) \\
\end{array}$ & $\begin{array}{c}M_{y} \\
(\mathrm{kN} \cdot \mathrm{m})\end{array}$ \\
\hline \multirow{4}{*}{$2 \mathrm{P}-3$} & \multirow{4}{*}{0.0149} & \multirow{4}{*}{31.44} & 梁柱(左) & 3 & 0 & 0.0149 & 0.0127 & 16.21 \\
\hline & & & 梁柱(右) & 1 & $\bigcirc$ & 0.0139 & 0.0116 & 15.46 \\
\hline & & & 柱脚(左) & 4 & & 0.0214 & 0.0152 & 24.46 \\
\hline & & & 柱脚(右) & 1 & $\bigcirc$ & 0.0139 & 0.0125 & 18.14 \\
\hline \multirow{4}{*}{$4 P-3$} & \multirow{4}{*}{0.0148} & \multirow{4}{*}{31.81} & 梁柱(左) & 1 & 0 & 0.0128 & 0.0104 & 18.82 \\
\hline & & & 梁柱(右) & 1 & $\bigcirc$ & 0.0128 & 0.0104 & 15.43 \\
\hline & & & 柱脚(左) & 3 & & 0.0153 & 0.0145 & 2241 \\
\hline & & & 柱脚(右) & 4 & & 0.0196 & 0.0150 & 20.97 \\
\hline \multirow{4}{*}{$6 P-3$} & \multirow{4}{*}{0.0143} & \multirow{4}{*}{27.98} & 梁柱(左) & 2 & $\bigcirc$ & 0.0141 & 0.0128 & 17.31 \\
\hline & & & 梁柱(右) & 1 & $\bigcirc$ & 0.0132 & 0.0108 & 14.69 \\
\hline & & & 柱脚(左) & 3 & & 0.0179 & 0.0157 & 2271 \\
\hline & & & 柱脚(右) & 3 & & 0.0179 & 0.0127 & 21.80 \\
\hline \multirow{4}{*}{$\begin{array}{c}4 \mathrm{P}-2 \mathrm{H} \\
-3\end{array}$} & \multirow{4}{*}{\multicolumn{2}{|c|}{0.0147}} & 梁柱(左) & 2 & $\bigcirc$ & 0.0141 & 0.0104 & 18.21 \\
\hline & & & 梁柱(右) & 1 & $\bigcirc$ & 0.0137 & 0.0112 & 16.13 \\
\hline & & & 柱脚(左) & 4 & & 0.0189 & 0.0092 & 2211 \\
\hline & & & 柱脚(右) & 3 & & 0.0158 & 0.0095 & 19.61 \\
\hline
\end{tabular}



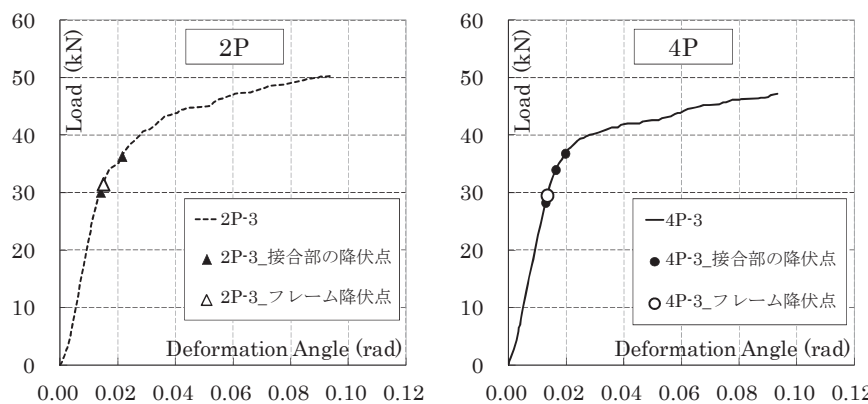

図 18 フレームの降伏点と接合部の降伏点の関係
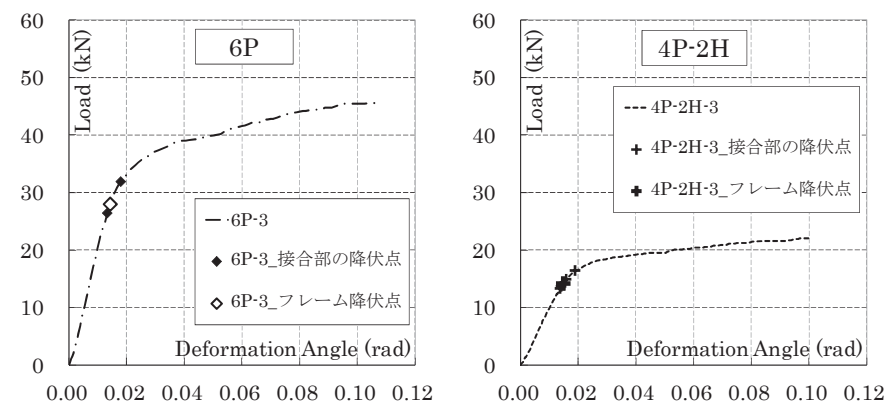

\section{2 門型フレーム試験のパラメータについての考察}

\subsection{1 門型フレーム試験のP $P$ - $y$ 関係}

図 9 右に全シリーズの $P-Y$ バイリニア曲線の比較, 表 6 にバイリ ニア特性值の比を示す。全シリーズ (4P- $2 \mathrm{H}$ を除く) を総体的に比 較すると, 初期剛性の比は 0.86 1.02, 降伏荷重の比は $0.92 \sim 1.05$ と大きな差はない。一方, 2 次剛性の比は 1.00 1.76 と差が大きい。 本試験の各シリーズのモーメント抵抗性能の相違は、降伏点までは あまり大きくないが，それ以降の違いが大きいと考えられる。

図 19 には, 図 9 のP-Yバイリニア曲線を, スパンをパラメータ とした比較, 鉛直荷重の有無による比較, 層高をパラメータとした 比較, 梁上耐力壁の有無による比較の, 4 つのパラメータ毎に分け て示す。

\subsection{2 スパンをパラメータとした比較}

スパンをパラメータとした比較（図 19）についての考察を行う。 初期剛性は大きな差はない。降伏荷重の比は $2 \mathrm{P}: 4 \mathrm{P}: 6 \mathrm{P}=1.05$ : $1.00 ： 0.92$ と大きな差はない（表 6) が，スパンが短いほど高い值 となっている。また，塑性域においても同一の層間変形角における 荷重值はスパンが短いほど高くなっている。すべての試験体で接合 部の仕様は同じなので, 荷重值が高いということは, 同一の層間変 形角における接合部の回転角が大きくなっていると考えられる。

5.1 節では, 1 つの門型フレームの左右（フレームの圧縮側・引張 側）の接合部の回転角に, 材せい寸法が与える影響について考察を した。ここでは, スパンの異なる門型フレームどうしの接合部の回 転角に，材せい寸法が与える影響について考察を行う。

図 20 に各接合部の回転角と閔型フレームの層間変形角の関係を 示す。梁柱接合部では左右ともに回転角の大きさは $2 \mathrm{P}, 4 \mathrm{P}, 6 \mathrm{P} の$ 順となった。特に塑性域ではその差は顕著であった。柱脚接合部(左) では, 各シリーズの接合部の回転角はほぼ同じとなった。柱脚接合 部（右）では，2P の回転角が大きく，4P と $6 \mathrm{P}$ はほぼ同じとなっ た。スパンが短いほど接合部の回転角が大きくなる原因は, 材せい 寸法の影響と考えられる。木質ラーメン構造は一般的に, 梁材, 柱 材などの母材の変形よりも，接合部の変形が大きい。本試験の引き ボルト式接合部についても同様である。門型フレームに水平荷重を 加えた場合，部材はほぼ剛体に近い状態で，接合部が変形をしてい く。門型フレームに一定の層間変形角を与えた場合, 柱の部材角は スパンによらず，ほぼ同じ值となると考えられる。しかし，梁が接 合部の圧縮端付近を回転中心として回転すると, 梁の部材角はスパ ンが短い方が大きくなると考えられる。図 20 に示したスパンによ る接合部の回転角の相違のメカニズムは以上ように考えられる。
4 章での考察では, 仮想降伏荷重の值は, SNAP では $2 \mathrm{P} \fallingdotseq 4 \mathrm{P} \fallingdotseq$ $6 \mathrm{P}$ ，稲山式では $2 \mathrm{P}<4 \mathrm{P}<6 \mathrm{P}$ ，試験值では $2 \mathrm{P}>4 \mathrm{P}>6 \mathrm{P}$ となった。 SNAP では，部材の曲げ変形分の差であった。稲山式では，フレー ムの引張側の柱軸力の影響により，スパンの短いシリーズほど仮想 降伏荷重の值の低下が大きかった。試験值は稲山式による数值計算 と反対の結果になった。 4 章では, 接合部の回転バネ, 部材の曲げ, 柱軸力の影響の 3 つ以外にフレームの変形に大きな影響を与える要 因があるのではないかと考えた。

その要因は，材せい寸法の影響であると考えられる。スパンが異 なると，梁のプロポーション（材せいと材長の比）が異なる。その 影響で梁柱接合部の回転角が異なり，フレームの耐力が異なる。

6.1 節で考察を行った 1 つの門型フレームの接合部の降伏挙動に ついては複合応力の影響が大きかったが，スパンをパラメータとし た比較においては, 複合応力の影響よりも, 材せい寸法の影響の方 が大きいと考えられる。

\section{2 .3 鉛直荷重の有無による比較}

鉛直荷重の有無による比較（図 19）についての考察を行う。 $6 \mathrm{P}-\mathrm{DL}$ の鉛直荷重の設定は，2.2 節の説明通り，当該層の一般的 な床荷重を想定したものである。また、接合部のせん断抵抗要素は, ほぞを設けて，モーメント，軸力と基本的には独立としている

初期剛性は， $6 \mathrm{P}-\mathrm{DL} / 6 \mathrm{P}=1.02 / 0.87=1.17$ と $6 \mathrm{P}-\mathrm{DL}$ の方が高 くなった（表 6)。鉛直荷重がかかると，その分だけフレームの引張 側の引張軸力が相殺されて, 柱脚接合部の見かけの剛性が上がる。 降伏荷重の比は 1.07 と少し高くなった。仮想降伏点と終局点の荷重 值の比は $1.01,2$ 次剛性の比は 1.03 となっていることから, 降伏以 降の要素はほぼ同じと考えられる。鉛直荷重の梁柱接合部への影響 は、左右で剛性が高くなる側と低くなる側があるため，効果が相殺 されたものと考えられる。

本試験仕様のフレームにおいては，床荷重程度の荷重レベルであ れば，鉛直荷重ありの方が，剛性・耐力ともに高くなった。

\subsection{4層高をパラメータとした比較}

層高をパラメータとした比較（図 19）についての考察を行う。 $4 \mathrm{P}-2 \mathrm{H}$ は $4 \mathrm{P}$ と比べて, 降伏点から終局点までの, 荷重值の比は 0.45 0.47 となった（表 6 ）。荷重值の比は層高の比 $2600 \mathrm{~mm} / 5500 \mathrm{~mm} \fallingdotseq 0.47$ とほぼ同じ值となった。ほぼ同じ值となっ たことは，接合部に入力するモーメントが（モーメント）＝（負担 せん断力） $\times($ 層高 $) \times （$ 反曲点高比）となるので，荷重值が層高 に反比例することによると考えられる。 


\section{2 .5 梁上耐力壁の有無による比較}

梁上耐力壁の有無による比較（図 19）についての考察を行う。 4P-SW は 4P と比べて, 降伏荷重の比は 1.04 とほぼ同じとなった。 初期剛性の比は 0.86 と低い值となったが，2 次剛性の比は 1.76 と 高くなった。

\section{7. まとめ}

本報では，6 シリーズの門型フレーム試験および接合部試験を行 い，様々な設計条件のパラメータを持つ木質ラーメン構造の構造設 計のクライテリアを検討するための資料を得るために，フレームの $P-Y$ 関係，接合部の $M-\theta$ 関係について考察を行った。

本報の仕様による引きボルト式接合部の門型フレームの $P^{-} Y$ 関係

について，以下のことがわかった。

・ スパンをパラメータとした比較 $(2 \mathrm{P}, 4 \mathrm{P}, 6 \mathrm{P})$ においては, 複 合応力の影響よりも，材せい寸法の影響の方が大きいので， ス パンの短いフレームの方が，耐力は高い值となった。

・鉛直荷重の有無による比較（6P, 6P-DL）においては, 接合部 にシアキーを設けたものは，一般的な床荷重程度であれば，鉛 直荷重による引張側の柱軸力の相殺による影響が大きいので, 鉛直荷重ありの方が，剛性・耐力ともに高くなった。

・層高をパラメータとした比較 $(4 \mathrm{P}, 4 \mathrm{P}-2 \mathrm{H})$ においては, (モー メント $)=($ 負担せん断力 $) \times （$ 層高 $) \times （ 反$ 曲点高比）の式 の通り，負担せん断力は層高に反比例の関係だった。

・梁上耐力壁の有無による比較 $(4 \mathrm{P}, 4 \mathrm{P}-\mathrm{SW})$ においては, 本報 の梁上耐力壁の仕様においては, 降伏荷重は梁上耐力壁の有無 ともに，ほぼ同じ值となった。

・ 門型フレームの各接合部の降伏順序の決定においては，材せい 寸法の影響, 正負非対称, 複合応力の影響の 3 つの要素のうち, 複合応力の影響が大きいと考えられる。

また, 本報の仕様による引きボルト式接合部の $M-\theta$ 関係について, 以下のことがわかった。

・門型フレームの接合部は, 材せい寸法の影響により, フレーム の圧縮側の方が接合部の回転角が大きくなるため，負担モーメ ントも大きくなる。

・ 部材の引張軸力の影響により, 梁柱接合部, 柱脚接合部ともに $M-\theta$ 関係の低減が生じる。

・ 部材のせん断力の影響により, 若干の $M-\theta$ 関係の低減が生じる。 また, $Q-\delta$ 関係については, せん断スパンが短い方が, 剛性・ 耐力が高い值となる。

本報の仕様による門型フレームの構造芯モデルによる数值計算に ついて，以下のことがわかった。

- SNAP を用いた数值計算では, スパンの大小, 鉛直荷重の有無, 梁上耐力壁の有無にかかわらず, 初期剛性, 仮想降伏点, 2 次 剛性とも，ほぼ同じ值となった。

・稲山式による数值計算では, スパンをパラメータとした比較に おいては, 仮想降伏荷重の值は, 試験值とは逆の結果となった。

今後, 材せい寸法の影響, 複合応力の影響を適切に考慮できるよ うな解析モデルを用いて数值計算を行い, スパン, 層高, 鉛直荷重, 梁上耐力壁などの影響を含めて, 門型フレームのP P- $Y$ 関係の推定を 行うことを考えている。
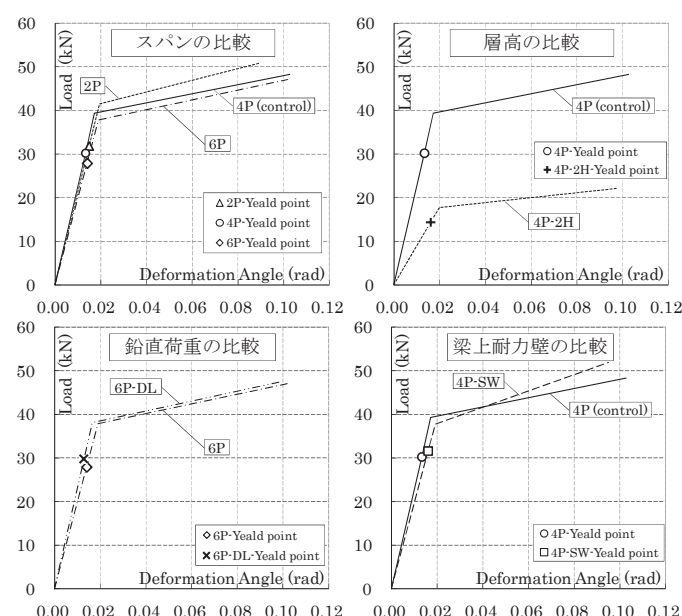

$\begin{array}{lllllll}0.00 & 0.02 & 0.04 & 0.06 & 0.08 & 0.10 & 0.12\end{array}$

$\begin{array}{llllllllllllll}0.00 & 0.02 & 0.04 & 0.06 & 0.08 & 0.10 & 0.12 & 0.00 & 0.02 & 0.04 & 0.06 & 0.08 & 0.10 & 0.12\end{array}$

図 19 パラメータごとの $P-y$ バイリニア曲線の比較
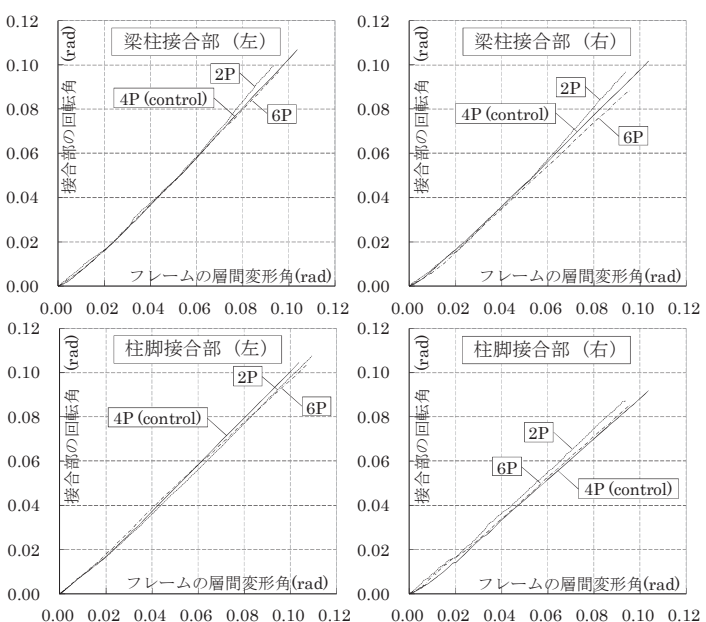

図 20 スパンの比較——

接合部の回転角ーフレームの層間変形角の関係

表 6 4P(control)を 1 としたときの $P-Y$ バイリニア特性値の比

\begin{tabular}{lcccccccc}
\hline 試験 体 & \multicolumn{2}{c}{ 降伏点 } & \multicolumn{2}{c}{ 仮想降伏点 } & \multicolumn{2}{c}{ 終局 点 } & 初期胴性 & 2次剛性 \\
シリーズ & $\gamma_{y}$ & $P_{y}$ & $\gamma_{v}$ & $P_{v}$ & $\gamma_{u}$ & $P_{u}$ & $K_{1}$ & $K_{2}$ \\
\hline $2 \mathrm{P}$ & 1.12 & 1.05 & 1.12 & 1.05 & 0.87 & 1.05 & 0.94 & 1.31 \\
\hline $4 \mathrm{P}(\mathrm{control})$ & 1.00 & 1.00 & 1.00 & 1.00 & 1.00 & 1.00 & 1.00 & 1.00 \\
\hline $6 \mathrm{P}$ & 1.06 & 0.92 & 1.11 & 0.96 & 0.99 & 0.97 & 0.87 & 1.05 \\
\hline $6 \mathrm{P}-\mathrm{DL}$ & 0.97 & 0.98 & 0.96 & 0.97 & 0.96 & 0.98 & 1.02 & 1.08 \\
\hline $4 \mathrm{P}-2 \mathrm{H}$ & 1.21 & 0.47 & 1.15 & 0.45 & 0.95 & 0.46 & 0.39 & 0.54 \\
\hline $4 \mathrm{P}-\mathrm{SW}$ & 1.21 & 1.04 & 1.11 & 0.96 & 0.92 & 1.07 & 0.86 & 1.76 \\
\hline
\end{tabular}

\section{参考文献}

1）景山誠，村上雅英，小松幸平：曲げモーメントとせん断力の複合応力を受 ける木質ラーメン接合部の構造性能評価法に関寸る研究, 日本建築学会構 造系論文集，No.647, pp165-173，2010.1

2）景山誠，村上雅英 : 鉛直荷重の影響を受ける木質ラーメンの水平せん断挙 動に関する研究，日本建築学会構造系論文集，No.661, pp581-590, 2011.3 3）小松幸平, 川元紀雄, 原田真樹 : 長期荷重を受ける集成材半剛節門形ラメンの変形解析，木材学会誌, Vol. 39, No.12, pp. 1393-1403, 1993.12.

4) 中川学、五十田博、岡野瑛貴 : 木質ラーメン構造, 軸組構造, 併用構造の 耐震性能評価と実大振動台実験, 日本建築学会構造系論文集, No.636, pp.321-330, 2009.2

5）日本建築学会編：木質構造 設計規準 - 同解説一許容応力度 - 許容耐力設 計法一, 日本建築学会, pp108-110, 2006

6) 日本建築学会編：木質構造接合部設計マニュアル，日本建築学会， pp295-311, 2009 